Enver Zerem Goran Imamović Safet Omerović

\section{Percutaneous treatment of symptomatic non-parasitic benign liver cysts: Single-session alcohol sclerotherapy versus prolonged catheter drainage with negative pressure}

Published online: 20 December 2007

(C) European Society of Radiology 2007

The online version of the original article can be found at http://dx.doi.org/10.1007/ s00330-007-0760-5.

\section{E. Zerem · G. Imamović}

University Medical Center,

75000 Tuzla, Bosnia and Herzegovina

S. Omerović

General Hospital Mostar,

88000 Mostar, Bosnia and Herzegovina

E. Zerem $(\bowtie)$

The University Clinical Center Tuzla,

Trnovac bb,

75000 Tuzla, Bosnia and Herzegovina

e-mail: zerem@inet.ba

Tel: +387-618-98202

Fax: +387-352-66485
Please note that there is a spelling inaccuracy of the second and third author's last name in the online version of the article. The correct spelling is Goran Imamović and Safet Omerović as given in the pdf version. 